\title{
The taxonomic status of Hyla roeschmanni De Grys, 1938 (Anura: Hylidae)
}

\author{
JOSÉ M. PADIAL ${ }^{1}$, JÖRN KÖHLER ${ }^{2} \&$ IGNACIO DE LA RIVA ${ }^{1 *}$ \\ ${ }^{1}$ Department of Biodiversity and Evolutionary Biology, Museo Nacional de Ciencias Naturales-CSIC, C/ José \\ Gutiérrez Abascal 2, 28006 Madrid, Spain. \\ ${ }^{2}$ Department of Zoology, Hessisches Landesmuseum Darmstadt Friedenplatz 1, 64283 Darmstadt, Germany. \\ *Corresponding author: iriva@mncn.csic.es
}

\begin{abstract}
The taxonomic status of Hyla roeschmanni De Grys, 1938 (Anura: Hylidae) is reviewed. We place Hyla roeschmanni as a junior synonym of Hypsiboas raniceps Cope, 1862. Because the holotype of Hyla roeschmanni was destroyed, we designate a neotype from Department Beni, Bolivia, and provide a description of the neotype.
\end{abstract}

Key words: Anura, Bolivia, Hyla roeschmanni, Hypsiboas raniceps, Hylidae, neotype, new synonym

\section{Introduction}

Much taxonomic research has been accomplished on Bolivian frogs during the last fifteen years (e.g. la Riva et al., 2000; Köhler, 2000). This work has lead to the clarification of many taxonomic problems, the description of new species, etc. Nevertheless, many species remain unnamed (unpublished personal data) and certain minor problems await resolution. For example, some species named long ago have not been reported again since their original descriptions. This is the case with Hyla roeschmanni De Grys, 1938 (see De la Riva, 1990; De la Riva et al., 2000).

According to Duellman (1977), the type specimen of H. roeschmanni was destroyed. This was confirmed subsequently by us via personal correspondence with the Zoological Museum of Hamburg (J. Hallermann, pers. comm., 2001). Moreover, H. roeschmanni is only known from the imprecise type locality "Provinz Beni, Bolivien, südliches Quellgebiet des Amazonas" (Province Beni, Bolivia, southern headwaters of the Amazon) (De Grys, 1938). The name has not been associated with any known population (Duellman 
in Frost, 1985). The type locality "Provinz Beni" is imprecise because Beni is the name of a large (213,564 square $\mathrm{km})$ Bolivian department composed of eight provinces, none of them named Beni; the author did not provide a specific locality. The departament of Beni mainly contains lowland savannas and gallery forests but also includes extensive areas of Amazonian forests in its northern part. Therein, the diversity of species of hylids is high, and both Amazonian and Chacoan species have been reported (Reichle, 1997; De la Riva et al., 2000). Although the assignment of $H$. roeschmanni to any known population is hampered by the lack of precise locality data, the original description is sufficiently detailed to compare it with the species occurring in the general region of the type locality. The description matches precisely with juveniles of Hypsiboas raniceps Cope, 1862, a common, broadly distributed species that occurs in most habitats of Beni department. We propose that Hyla roeschmanni is a junior synonym of Hypsiboas raniceps; because the holotype is lost and was apparently destroyed in World War II, we designate herein a neotype from Beni department, Bolivia.

\section{Material and methods}

For nomenclature of Hylidae we follow Faivovich et al. (2005) and for the synonymy we follow Frost (2004). Measurements were taken with a digital calliper to the nearest 0.01 mm, but following Hayek et al. (2001), for avoiding pseudo precision, we rounded all measurements to only one decimal. Webbing formulae follow Savage and Heyer (1967) as modified by Myers and Duellman (1982) and Savage and Heyer (1997). Museum abbreviations follow Leviton et al. (1985).

\section{Results}

\section{Hypsiboas raniceps Cope, 1862}

Hypsiboas raniceps Cope, 1862, Proc. Acad. Nat. Sci. Philadelphia, 14: 353. Syntypes: USNM 5403 (4 specimens), 5408 12160, 12172 (2 specimens) according to Cochran, 1961, Bull. U.S. Natl. Mus., 220: 62. Type locality: Not mentioned specifically. Type locality given as "Paraguay" by Cochran, 1961, Bull. U.S. Natl. Mus., 220: 62.

Hyla spegazzinii Boulenger, 1889, Ann. Mus. Civ. Stor. Nat. Genova, Ser. 2, 7: 247. Syntypes: MCSN (2 specimens) and BM 1947.2.12.76-77 (formerly 94.3.17.15) according to Condit, 1964, J. Ohio Herpetol. Soc., 4: 95; MCSN 29758A designated lectotype by Capocaccia, 1957, Ann. Mus. Civ. Stor. Nat. Genova, 69: 213. Type locality: "Colonia Resistancia, South Chaco, Argentine Republic". Synonymy by Cochran, 1955 "1954", Bull. U.S. Natl. Mus., $206: 96$.

Hyla goodfellowi Procter, 1921, Ann. Mag. Nat. Hist., Ser. 9, 7: 191. Holotype: BM 1947.2.23.4 (formerly 1920.11.29.23) according to Condit, 1964, J. Ohio Herpetol. Soc., 4: 90. Type locality: "Esperanza, [Departmento de Santa Cruz] E. Bolivia". Synonymy with Hyla spegazzini by Parker, 1928, Ann. Mag. Nat. Hist., Ser. 10, 2: 98. 
Hyla roeschmanni De Grys, 1938, Zool. Anz., 123: 315. Holotype: ZMH, now destroyed, according to Duellman, 1977, Das Tierreich, 95: 95; and J. Hallermann pers. comm. Type locality: "Provinz Beni, Bolivien, südliches Quellgebiet des Amazonas. Neotype: MNCN 42319 (field tag, JMP 1083) an adult male from Bella Vista, Province Iténez, Departamento de Beni, Bolivia (13 $16^{\prime}$ S, $\left.63^{\circ} 42^{\prime} \mathrm{W}\right)$, collected on 25 March 2003 by José M. Padial.

\section{Diagnosis}

A species of the Hypsiboas albopunctatus group (sensu Faivovich et al. 2005) distinguished from other species in the group by the following combination of characters: maximum SVL, $70 \mathrm{~mm}$ in males, $81 \mathrm{~mm}$ in females (Lutz, 1973; Cei, 1980); body robust; snout long, acuminate in dorsal view, rounded and protruding in profile; canthus rostralis slightly rounded in cross-section; loreal region concave; tympanic membrane and tympanic annulus distinct, round, its diameter about three-fifths eye length; supratympanic fold prominent, covering upper edge of tympanic annulus, reaching slightly behind insertion of arm; vomerine odontophores prominent, separated medially, between choanae; hind limbs long, slender; tibiotarsal articulation reaching beyond tip of snout; heels overlapping when limbs flexed perpendicular to axis of body; tarsal fold and tubercles on outer edge of tarsus absent; weak ulnar folds present; axillary membrane absent; fingers with basal webbing; toes about four-fifths webbed; well-developed, round terminal discs on fingers and toes, slightly smaller on toes; single distal subarticular tubercle under fourth finger; enlarged pollex rudiment with slightly projecting bony spine in adult males; nuptial excrescences absent in males; skin on dorsal surfaces smooth, with or without small tubercles; skin on throat tuberculate; skin on venter and ventral surfaces of thighs strongly granular; distinct transverse fold on chest; dorsal surfaces tan, pale grey or brown, with or without indistinct irregular dark transverse marks and flecks and/or small cream spots; loreal and tympanic region brown; ventral surfaces cream, sometimes with indistinct and irregular brown marbling and spotting on throat and chest; posterior flanks and hidden surfaces of thighs white to greyish-cream with bold dark brown spots or vertical bars.

\section{Description of neotype}

An adult male; body and extremities long and slender; head slightly longer than wide. Dorsal skin and throat smooth, belly and groins areolate, flanks warty, with low elongate warts; dorsal folds absent; supratympanic fold prominent, from posterior margin of the upper eyelid to the level of the arm insertion; tympanic membrane large, conspicuous, round to slightly oval; tympanic annulus thin, almost complete, but hidden in its dorsal margin; snout round in dorsal view, round to subacuminate in lateral profile; canthus rostralis sharp, concave in dorsal view; loreal region slighlty concave; narines slightly prominent, dorsolaterally oriented; tongue more or less circular, weakly bifurcated behind, barely free posteriorly; vomerine odontophores large, transverse, between choanae, almost in contact with each other and with choanae; about ten small vomerine teeth on each odontophore; choanae large, triangular, separated by a distance twice their diameter. Thenar tubercle large, elongate, almost twice as large as palmar tubercle; palmar tubercle 
small, low, cordiform; supernumerary tubercles abundant (up to five on a finger), round, smaller than subarticular tubercles; subarticular tubercles round, prominent; interdigital membrane between Fingers II-III-IV basal; finger lengths 3>2>1>4; discs large, round to slightly oval; prepollical spine present; no tubercles on heel and tarsus; inner metatarsal tubercle large, low, oval; outer metatarsal tubercle almost inconspicuous; subarticular tubercles large, round; supernumerary tubercles abundant, round, small, inconspicuous; toes with interdigital membrane well developed, webbing formula, I1-2II1-2III $1_{1 / 2}-2$ IV2$1 \mathrm{~V}$; toe discs large, round; toe lengths $4>3>5>2>1$.

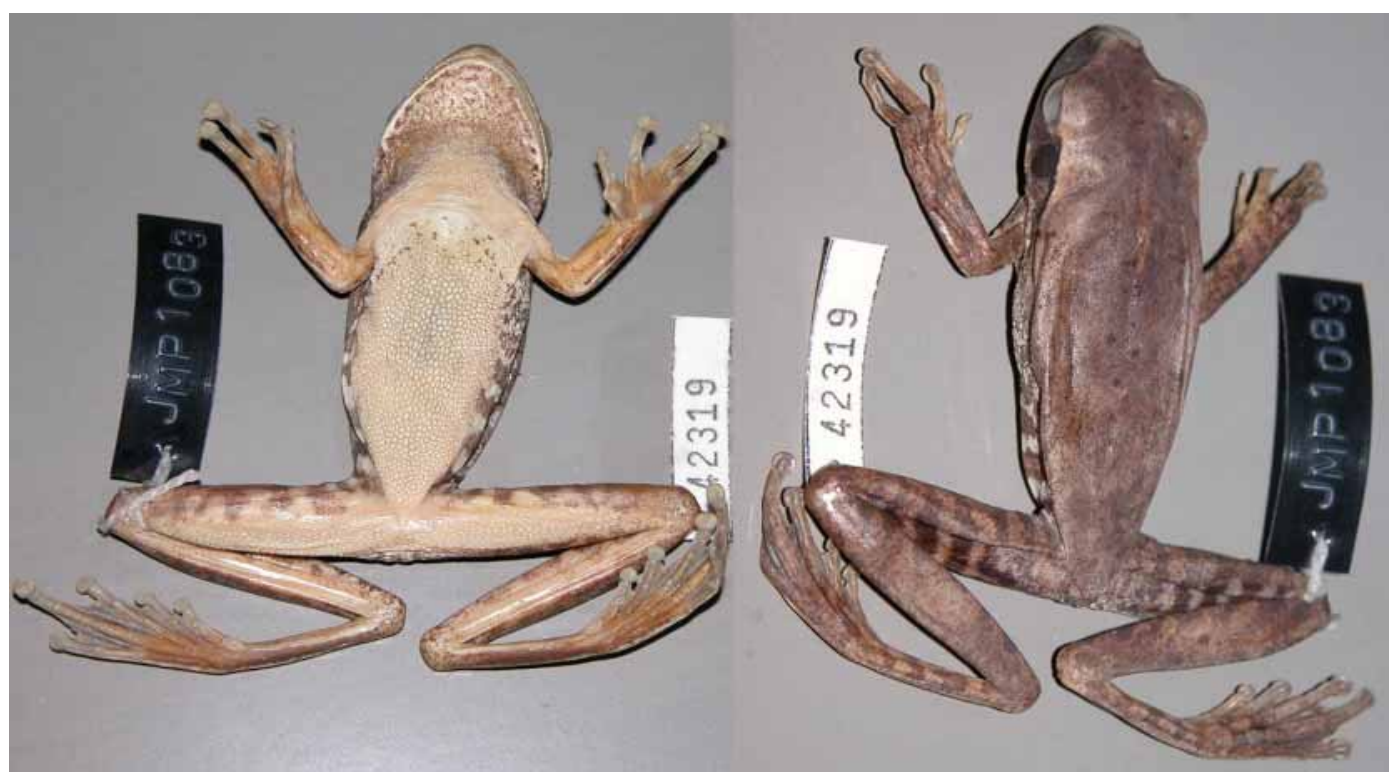

FIGURE 1. Ventral and dorsal view of the neotype of Hyla roeschmanni from Bellavista, Department Beni, Bolivia (MNCN 42319).

\section{Coloration in alcohol}

Dorsal surfaces dark brown with small, diffuse, irregular darker marks; flanks cream with vertical, diffuse, brown bars. Throat cream with dense dark brown mottling, chest with less mottling; belly immaculate cream; ventral surfaces of limbs cream; anterior and posterior surfaces pale brown with darker vertical bars, more contrasted on the posterior surface; ventral surfaces of hands and feet brown; tympanic membrane dark brown, supratympanic fold dark brown to black.

\section{Measurements (in millimeters)}

Snout-vent length, 61.4; head length (from posterior margin of the lower jaw to tip of snout), 20.6; head width (measured at level of rictus), 18.6; eye diameter, 7.4; eye-nostril distance, 5.3; internarial distance, 4.8; eye-eye distance (between anterior margins), 10.1; Finger III length, 2.4; tibia length, 33.9; foot length (from proximal border of inner metatarsal tubercle to tip of fourth toe), 26.5. 
The original description (De Grys, 1938) matches quite well the neotype, mostly regarding overall coloration (especially the striped coloration on hidden surfaces of thighs), the distinct transverse fold on chest, and tympanum condition and size. Minor discrepancies are: head length equal to head width in the holotype, probably because of different measurement points (i. e. posterior margin of the lower jaw vs. rictus); the fingers are described as free in the holotype, which could be a result of poor (dry) preservation; also the holotype did not have a rudimentary prepollex. The latter might be because of immaturity (as revealed by the smaller size [39 $\mathrm{mm} \mathrm{SVL}$ ] and coloration [see below]) and/ or that the holotype was a female. For additional information about the morphological variation in this species see Lutz (1973).

In the original description, the coloration is described as: dorsal surfaces light creamybrown. A dark brown triangular fleck between eyes, opening directed anteriorly; a longitudinal fleck on each shoulder and some irregular, less distinct flecks on posterior dorsum; limbs barred; posterior surfaces of thighs with vividly dark and light flecking. Some faded flecks on groin; belly white, without flecks. The description of the coloration resembles immature Hypsiboas raniceps. Juveniles are mostly pale green with an inverted triangular mark from the interorbital region to the middle of the dorsum (pers. obs.). During further development, this mark tends to reduce progressively while the remaining coloration becomes brownish.

\section{Acknowledgements}

JMP's work in Bolivia was financed by a grant of the Mutis programme of the MAE-AECI (Spain). JMP and IDIR are grateful to the following persons for the help and space provided at their respective institutions: M. Suárez, A. Justiniano, R. Vespa, R. Montaño, and L. Gonzles (Museo de Historia Natural Noel Kempff Mercado, Santa Cruz, Bolivia), and J. Aparicio (Colección Boliviana de Fauna, La Paz). JMP is indebted to Javier Heredia, Mario González and Silvia Ten for their companionship during the fieldwork in Beni. This work was partially funded by the projects REN/GLO 2001-1046 and CGL2005-03156 of the Spanish Ministry of Education and Science (I. De la Riva, Principal Investigator). We are indebted to Fernando Palacios for his decisive support, and to Jakob Hallermann for confirming that the original type of $H$. roeschmanni is indeed lost.

\section{Literature cited}

Cei, J.M. (1980) Amphibians of Argentina. Monitore zoologico italiano (N. S) Monographie, 2, $1-609$. 
De Grys, P. (1938) Hyla Roeschmanni spec. nov. Zoologischer Anzeiger, 124, 315-316.

De la Riva, I. (1990) Lista preliminar comentada de los anfibios de Bolivia con datos sobre su distribución. Bollettino del Museo regionale di Scienze Naturali Torino, 8, 261-319.

De la Riva, I., Khler, J., Ltters, S., \& Reichle, S. (2000) Ten years of research on Bolivian amphibians: updated checklist, distribution, taxonomic problems, literature and iconography. Revista E spañola de Herpetología, 14, 19-164.

Duellman, W.E. (1977) Liste der rezenten Amphibien und Reptilien, Hylidae, Centrolenidae, Pseudidae. Das Tierreich, 95, 1-225.

Faivovich, J., Haddad, C.F.B., García, P.C.A., Frost, D.R., \& Campbell, J.A. (2005) Systematic review of the frog family Hylidae, with special reference to Hylinae: phylogenetic analysis and taxonomic revision. Bulletin of the American Museum of Natural History, 294, 1-240.

Frost, D.R. (1985) Amphibian species of the world. A taxonomic and geographical reference. Allen Press and Association of Systematics Collections, Lawrence. 732 pp.

Frost, D.R. (2004) Amphibian Species of the World: an online reference. Available from: http:// research.amnh.org/herpetology/amphibia/index.html (Date of access 24 January 2006).

Hayek, L.A., Heyer, R.W. \& Gascon, C. (2001) Frog morphometrics: a cautionary tale. Alytes, 18, $153-177$.

Köhler, J. (2000) Amphibian diversity in Bolivia: a study with special reference to montane forest regions. Bonner zoologische Monographien, 48, 1-243.

Leviton, A.E., Gibbs Jr., R.H., Heal, E., \& Dawson, C.E. (1985) Standards in herpetology and ichthyology: Part I. Standard symbolic codes for institutional resource collections in herpetology and ichthyology. Copeia 1985, 802-832.

Lutz, B. (1973) Brazilian species of Hyla. University of Texas Press, Austin \& London. 265 pp.

Myers, C.W. \& Duellman, W.E. (1982) A new species of Hyla from Cerro Colorado, and other tree frog records and geographical notes from Western Panama. American Museum Novitates, 2752, 1-32.

Reichle, S. (1997) Frösche des Savannengebietes der Estación Biológica del Beni (EBB), Bolivien. Herpetofauna, 19 (106), 5-18.

Savage, J.M. \& Heyer, W.R. (1967) Variation and distribution in the tree-frog genus Phyllomedusa in Costa Rica, Central America. Beiträge zur Neotropischen Fauna, 5 (2), 111-131.

Savage, J.M. \& Heyer, W.R. (1997) Digital webbing formulae for anurans: A refinement. Herpetological Review, 28 (3), 131. 